\title{
SISTEM INFORMASI GEOGRAFIS FASILITAS KESEHATAN BPJS DI KOTA PALANGKA RAYA BERBASIS ANDROID
}

\author{
Licantik $^{\text {a,1,*, }}$, Nova Noor Kamala Sari ${ }^{\text {b,2 }}$, Nina Heldayanti ${ }^{\text {b,3 }}$ \\ ${ }^{a, 1}$ Universitas Palangka Raya, Kampus Tunjung Nyaho Jl. Yos Sudarso Palangka Raya 73112 \\ b,2 Universitas Palangka Raya, Kampus Tunjung Nyaho Jl. Yos Sudarso Palangka Raya 73112 \\ b,3 Universitas Palangka Raya, Kampus Tunjung Nyaho Jl. Yos Sudarso Palangka Raya 73112 \\ ${ }^{1}$ herbayuli_2005@yahoo.co.id*; ${ }^{2}$ novanoorks@it.upr.ac.id; ${ }^{3}$ ninaheldayanti93@ gmail.com \\ * corresponding author
}

\section{A B S TR ACT}

\section{Kata Kunci}

Geographic Information System (GIS) the BPJS health facility

Android
Today the development of technology has been increasing rapidly as well as the use of android smartphones in the field of information systems. It is familiar among the public because it can help in getting the information in a fast and accurate way particularly in an emergency situation. Human needs for information, one of them is information of health facilities in collaboration with Badan Penyelenggara Jaminan Sosial (BPJS) or Agency of Social Security. The purpose of this study is to produce an Android-based application that can facilitate the public in getting information of health facilities in collaboration with BPJS in Palangkaraya. The method applied in the system development in this study is the Waterfall model which consists of five stages, namely, need analysis, system of design, program code writing, program testing, and program implementation. In addition, in creating process, the program uses Android studio software with java programming language and XAMPP connection database, up to UML (Unifield Modeling Language) to depict the system to be made. From this study, the test result shows that the functionality of the BPJS health facility Geographic Information System (GIS) in Palangkaraya City is going well and is in accordance with its function. This android-based application system can display online maps of BPJS health facility locations as well as detailed information from BPJS health facilities in Palangkaraya.

\section{Pendahuluan}

Perkembangan teknologi informasi sekarang ini semakin marak dan berkembang pesat. Salah satu aspek teknologi yang sedang berkembang adalah teknologi mobile pada perangkat telepon pintar (smartphone). Teknologi smartphone yang sedang menjadi tren saat ini adalah adanya sistem operasi berbasis android. Banyak kalangan praktisi dan akademisi mengembangkan aplikasi berbasis android, sehingga dinilai dapat memberikan banyak kemudahan dan keuntungan bagi penggunanya.

Salah satu contoh pedayagunaan smartphone berbasis android yaitu pada bidang geografis dengan mengembangkan sebuah sistem terpadu yang memiliki banyak fasilitas dan dapat membantu, memproses, menyimpan serta mengorganisasikan informasi geografis. Perkembangan teknologi 
tersebut kemudian lebih dikenal dengan Geographics Information System (GIS) atau Sistem Informasi Geografis (SIG).

Jika ditinjau dari segi pemanfaatannya, teknologi dan aplikasi SIG sebenarnya dapat dimanfaatkan secara luas di berbagai bidang salah satunya pada bidang penyelenggaraan jaminan sosial. SIG dapat digunakan untuk memetakan fasilitas kesehatan (faskes) yang bermitra dengan Badan Penyelenggara Jaminan Sosial (BPJS).

Badan Penyelenggara Jaminan Sosial atau disingkat BPJS merupakan Badan Usaha Milik Negara yang bergerak dibidang penyelenggaraan program jaminan kesehatan. Untuk menjalankan fungsinya secara merata BPJS mempunyai kantor cabang yang tersebar di beberapa kota di Indonesia, salah satunya yaitu BPJS cabang Kota Palangkaraya. BPJS cabang Kota Palangkaraya menyelenggarakan jaminan sosial untuk masyarakat wilayah Kota Palangkaraya bermitra dengan beberapa Fasilitas kesehatan (Faskes). Fasilitas kesehatan (faskes) merupakan suatu sarana dan prasarana alat atau tempat yang digunakan untuk menunjang maupun menyelenggarakan upaya pelayanan kesehatan.

Pada penyelenggaran BPJS cabang Kota Palangkaraya masih terdapat kendala yang dihadapi oleh masyarakat. Kurangnya informasi mengenai persebaran fasilitas kesehatan dan informasi mengenai fasilitas kesehatan itu sendiri, membuat masyarakat kebingungan pada saat memilih dan mencari letak posisi fasilitas kesehatan mana yang akan mereka kunjungi untuk berobat menggunakan kartu BPJS, dikarenakan tidak semua fasilitas kesehatan yang berada di kota Palangkaraya melayani jasa untuk peserta BPJS.

Dengan dirancangnya sistem informasi geografis ini kita dapat memetakan fasilitas kesehatan yang melayani BPJS sehingga diharapkan dapat membantu dan memfasilitasi masyarakat dalam mencari informasi letak lokasi fasilitas kesehatan tersebut. Dan seiring dengan perkembangan teknologi sistem informasi pemetaan ini sudah dapat diakses melalui perangkat Smartphone android yang menawarkan fleksibilitas yang besar dan memungkinkan pengguna memperoleh hasil informasi secara cepat sesuai dengan kebutuhan.

Berdasarkan uraian yang telah disebutan di atas maka dari pada itu penulis mengajukan judul "Rancang Bangun Sistem Informasi Geografis Fasilitas Kesehatan BPJS berbasis Android di kota Palangkaraya" guna sebagai solusi dalam membantu masyarakat dalam mencari letak lokasi fasilitas kesehatan BPJS tersebut. Android yang merupakan perangkat yang mudah dan banyak digunakan oleh user menjadi salah satu pertimbangan dalam perancangan aplikasi sistem ini.

\section{Metodologi Penelitian}

Dalam perancangan pembuatan SIG berbasis android ini, metodologi pelaksanaan penelitian yang dilakukan meliputi:

\section{a. Identifikasi Awal}

Merupakan tahapan awal yang dilakukan adalah dengan melakukan identifikasi persoalan yang menjadi alasan pembuatan Sistem Informasi Geografis Fasilitas BPJS Berbasis Android di kota Palangkaraya yang kemudian dilakukan perumusan masalah.

b. Metode Pengumpulan Data

Merupakan tahap pengambilan data atau sampel yang berhubungan dengan permasalahan yang sedang dibahas. Dalam pengumpulan data tersebut menggunakan dua teknik pengumpulan data yaitu Studi Pustaka dan Observasi. 
c. Tahap Pengolahan Data

Pada tahap ini adalah pengolahan data yang telah terkumpul ke dalam sistem informasi geografis dan akan dibangun menggunakan Google Maps API untuk dapat menampilkan peta digital wilayah kota Palangka Raya dan menyimpan data tersebut kedalam sebuah database MySQL. Metodologi yang digunakan dalam perancangan dan pembuatan aplikasi perangkat lunak Sistem Informasi Geografis Fasilistas kesehatan BPJS Berbasis Android di Kota Palangkaraya adalah dilakukan dengan menggunakan metode pengembangan system Waterfall Model.

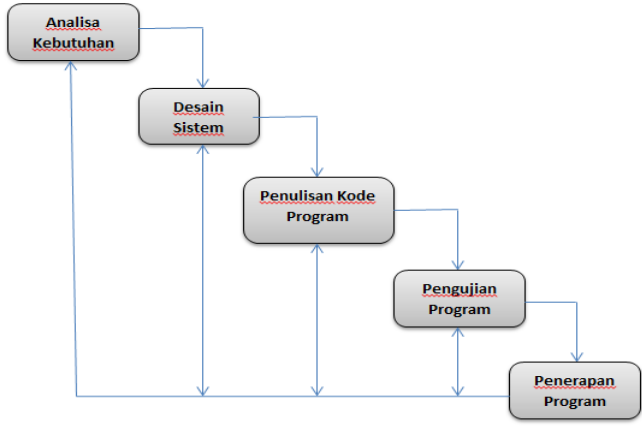

Gambar 2.1 Model Waterfall

a) Analysis (Analisa Kebutuhan)

Pada tahap ini identifikasi persoalan yang menjadi alasan pembuatan sistem informasi geografis Fasilitas kesehatan BPJS di Kota Palangkaraya yang kemudian diadakan perumusan masalah analisis sistem dan dilakukan pengumpulan data yang dibutuhkan untuk membangun sistem informasi geografis ini. Pada tahap ini dilakukan perancangan Bisnis Proses untuk menggambarkan alur kegiatan langkah per langkah, Flowchart untuk menggambarkan urutan proses secara mendetail dan hubungan antara suatu proses dengan proses yang lainnya, dan Unified Modeling Language (UML) untuk membangun sistem perangkat lunak.

1. Teknologi/peralatan yang digunakan dalam penelitian ini di spesifikasikan dalam hardware dan software, yaitu sebagai berikut :

1. Perangkat keras atau hardware yang terdiri dari :

○ Perangkat Perangkat laptop dengan spesifikasi Processor Intel (R) Core (TM) i5-8265U CPU @ 1.60Ghz 1.80Ghz, RAM 4GB, 256SSD

○ GPS Handheld/Mobile

- Smartphone Android (minimal versi android Kitkat)

2. Perangkat lunak atau software, yang terdiri dari :

- Sistem Operasi Microsoft Windows 1064 Bit

○ Notepad++

- Android Studio

- Java Development Kit (JDK), agar dapat membaca bahasa pemrograman Java.

- Android Software Development Kit (SDK)

- Database Software MySQL

- Nox Virtual Android

2. Flowchart dan Usecase Sistem 


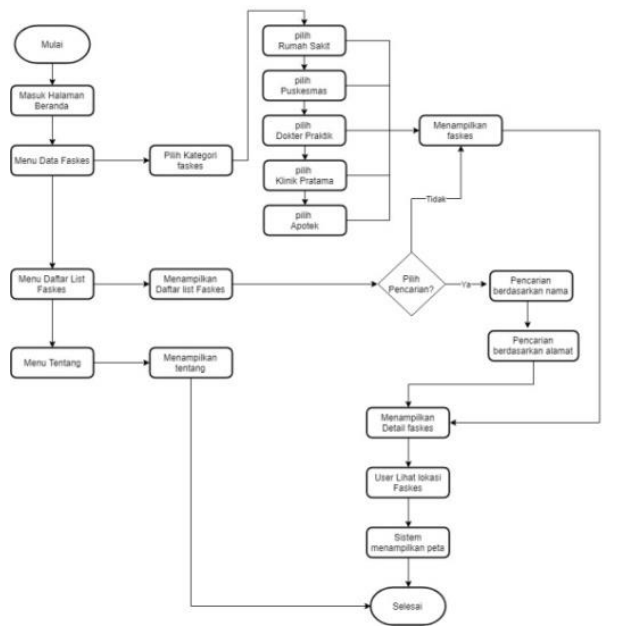

Gambar 2.2 Flowchart Penerapan Sistem

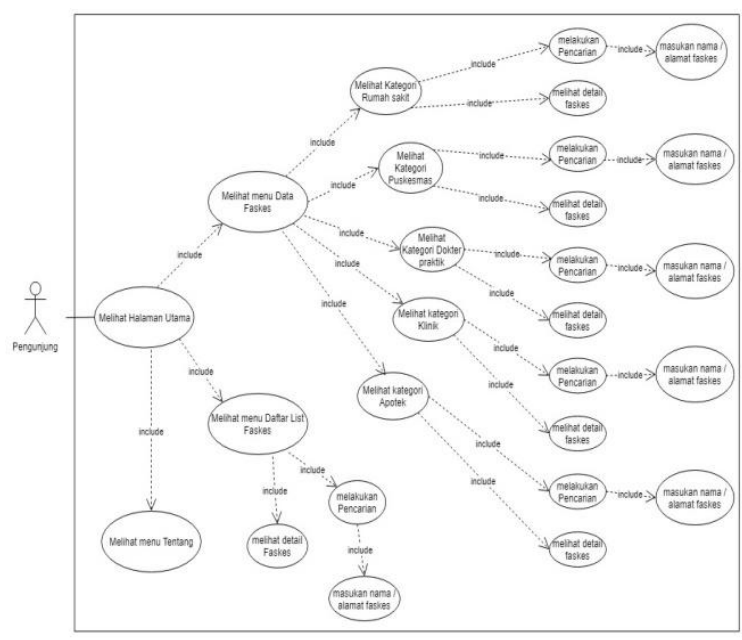

Gambar 2.3 Usecase Sistem

b) Design (Desain Sistem)

Proses desain ini mempresentasikan hasil analisis kedalam bentuk rancangan sistem yang dapat dimengerti perangkat lunak sebelum dimulai pembuatan program seperti struktur tabel, desain navigasi dan desain interface.

c) Coding (Penulisan Kode Program)

Penulisan kode program merupakan tahap penerjemahan desain sistem yang telah dibuat ke dalam bentuk perintah-perintah yang dimengerti komputer dengan mempergunakan bahasa pemrograman java. Adapun Software yang digunakan untuk membangun aplikasi android ini menggunakan Android Studio, Android Software Development Kit (SDK), Java Development Kit (JDK), Dan menggunakan database server MySQL.

d) Testing (Pengujian Program)

Pada tahap pengujian sistem ini akan dilakukan dengan pengujian Blackbox Testing, dimana aplikasi akan dibagikan dan diterapkan oleh tiga orang untuk mengetahui hasil sistem seperti apa, apakah hasil sudah sesuai dengan rancangan awal dan berjalan dengan baik ataukah perlu diperbaiki lagi.

\section{e) Penerapan Program}

Pada tahap ini program yang sudah selesai mulai diterapkan penggunaannya kepada user yang menggunakan program ini.

\section{Hasil dan Pembahasan}

Hasil dari penelitian ini menghasilkan dua buah sistem yang terdiri dari sistem web untuk admin dalam mengelola data faskes dan SIG berbasis android yang digunakan pengunjung untuk mencari petaa lokasi faskes BPJS di Kota Palangkaraya.

\subsection{Implementasi Interface Web Admin}

Implementasi antar muka admin ini merupakan proses pengelolaan data faskes oleh admin pada web untuk halaman admin. Dibawah ini merupakan halaman login untuk admin dengan memasukan username $=$ admin dan password $=$ admin 


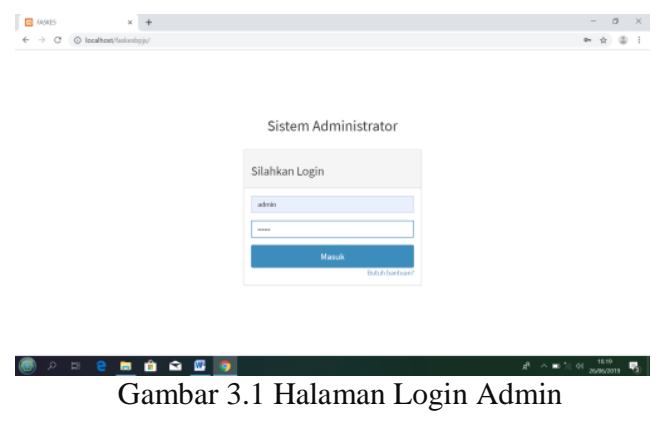

Setelah berhasil login, admin akan masuk ke halaman utama admin yang berisi beberapa fitur didalamnya yaitu menu kelola data faskes, kelola data admin dan logout.

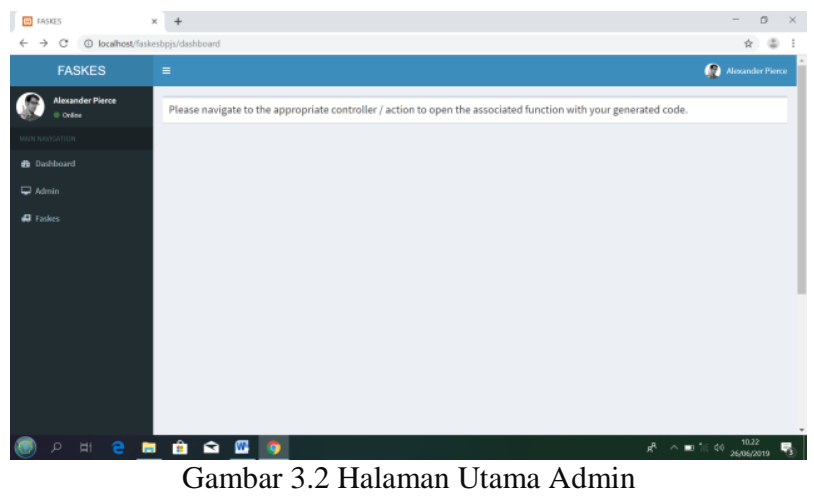

Apabila pada halaman ini admin memilih menu data faskes, maka akan masuk ke halaman kelola data faskes seperti pada gambar dibawah ini dengan data faskes berjumlah 46 data.

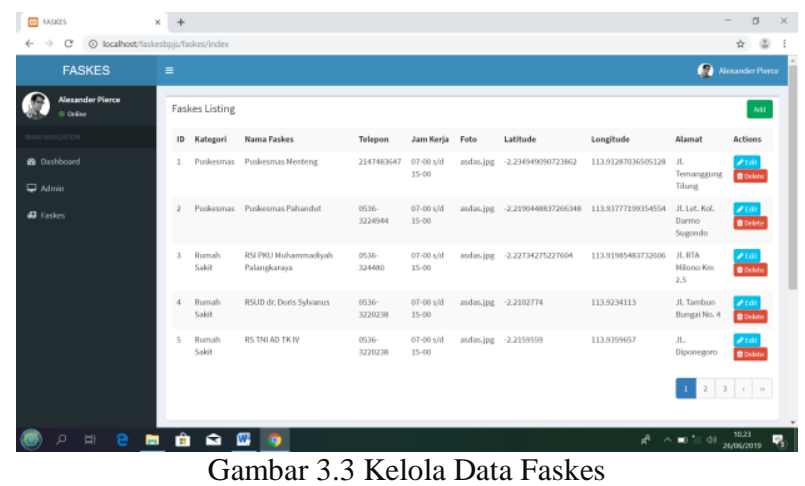

Pada halaman kelola data Faskes ini terdapat beberapa fitur kelola yaitu tambah data, edit dan hapus. Sedangkan untuk data admin ini adalah halaman kelola data admin dengan fitur kelola didalamnya yaitu tambah data, edit dan hapus data seperti gambar dibawah ini.

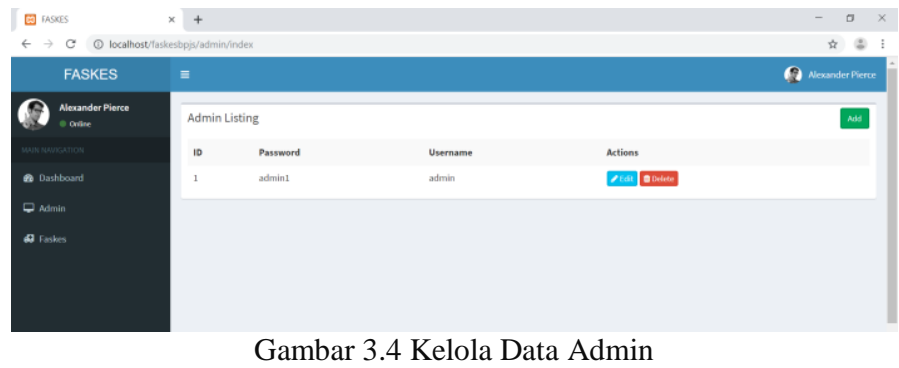


apabila admin memilih logout maka admin akan keuar dari halaman admin dan untuk kembali admin harus login terlebih dahulu.

\subsection{Implementasi Interface SIG berbasis android (Pengunjung)}

Pada tahapan ini akan diterangkan dan ditampilkan secara singkat penggunaan sistem informasi geografis pencarian Faskes BPJS wilayah Kota Palangka Raya beserta penerapannya. Untuk dapat menggunakan aplikasi sistem informasi geografis pencarian Faskes BPJS, sebelumnya yang harus dilakukan adalah menginstal aplikasi Faskes BPJS pada smartphone android.

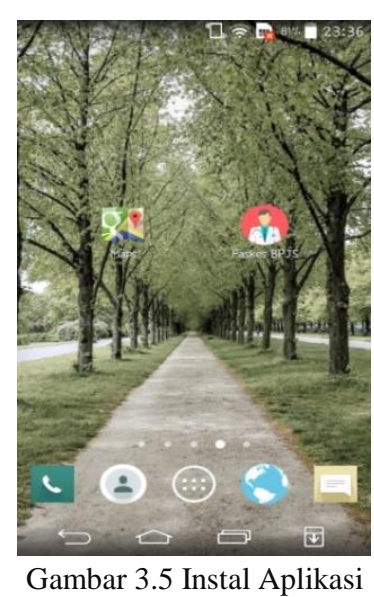

Apabila aplikasi sudah terinstal pada android seperti gambar diatas, selanjutnya buka aplikasi dan akan tampil halaman-halaman selanjutnya pada aplikasi SIG Faskes BPJS untuk melakukan pencarian lokasi Faskes BPJS.

\subsubsection{Tampilan Halaman Utama}

Pada saat pengunjung membuka aplikasi sistem informasi geografis Faskes BPJS ini akan langsung masuk ke halaman utama aplikasi seperti pada gambar dibawah ini, tampilan halaman utama yang menunjukan peta lokasi faskes BPJS yang dilengkapi dengan fitur menu data faskes, daftar list faskes dan tentang.

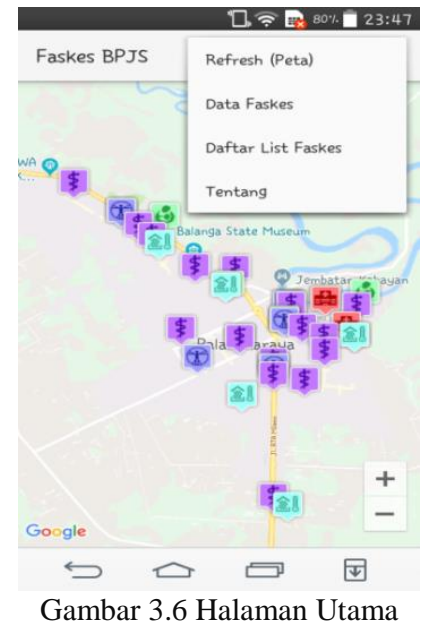


Apabila pengguna memilih fitur data faskes maka sistem akan menuju halaman pencarian seperti gambar berikutnya.

\subsubsection{Tampilan Halaman Data Faskes}

Apabila pengunjung memilih fitur data faskes maka sistem akan menuju halaman data faskes yang sudah dikelompokan sesuai kategori faskesnya, tampilannya seperti gambar berikutnya

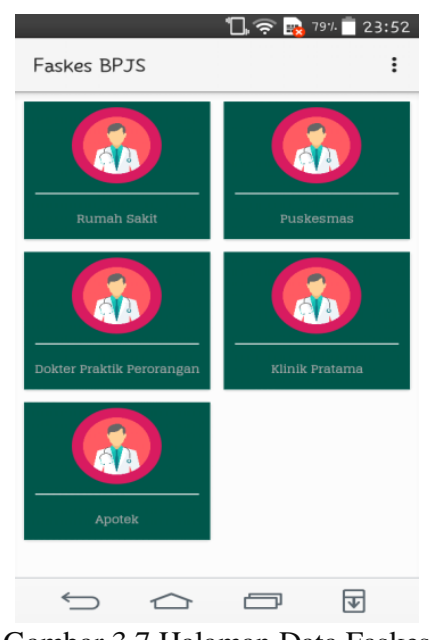

Gambar 3.7 Halaman Data Faskes

Apabila pengunjung memilih kategori puskesmas maka aplikasi akan menampilkan data faskes yang berupa puskesmas.

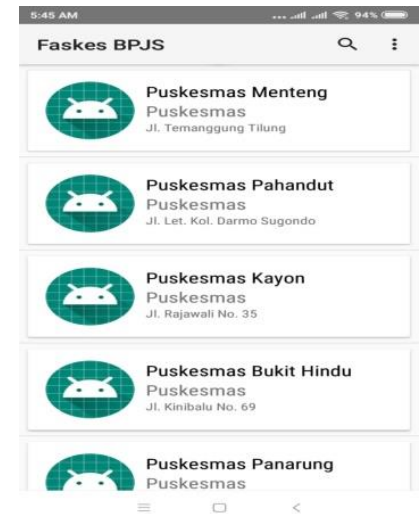

Gambar 3.8 Halaman Data Faskes Puskesmas

Apabila dipilih salah satunya maka akan menampilkan detail dari faskes tersebut yang berisikan keterangan berupa nama faskes, kategori faskes, alamat faskes, jam layanan, dan kontak dari faskses tersebut. Sebagai contoh apabila pengunjung memilih faskes Puskesmas Kayon maka aplikasi akan menampilkan detail tentang Puskesmas Kayon seperti gambar dibawah ini. 


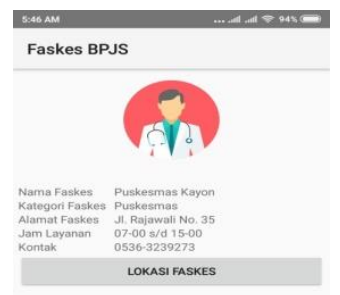

Gambar 3.10 Halaman detail Faskes Puskesmas Kayon

Pada detail faskes ini terdapat tombol lokasi faskes yang apabila di klik akan menampilkan peta lokasi faskes tersebut
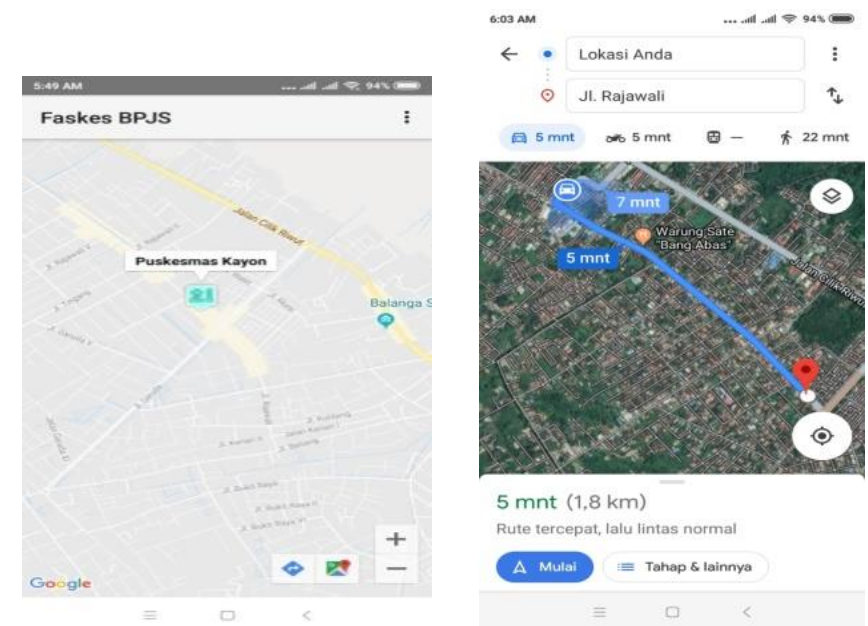

$5 \mathrm{mnt}(1,8 \mathrm{~km})$

Rute tercepat, lalu lintas normal

$\triangle$ Mulai $\equiv$ Tahap \& lainnya

Gambar 3.11 Peta lokasi dan rute puskesmas kayon

\subsubsection{Tampilan Halaman Daftar List Faskes}

Apabila pengunjung memilih fitur daftar list faskes maka sistem akan menuju halaman yang berisikan seluruh data faskes BPJS, tampilannya seperti gambar berikutnya.

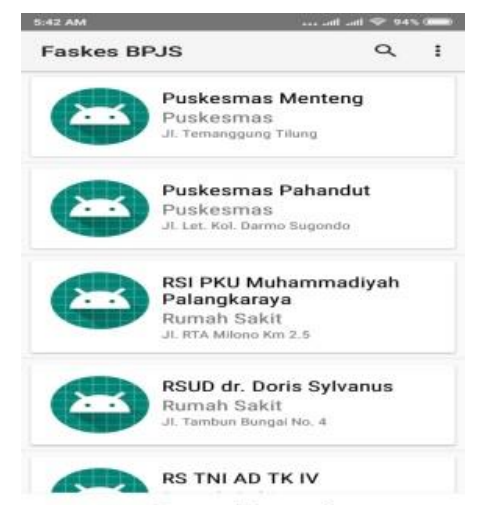

Gambar 3.12 Halaman Daftar List Faskes

Pada fitur ini juga terdapat menu pencarian yang dapat digunakan untuk mencari faskes berdasarkan nama maupun alamat. 

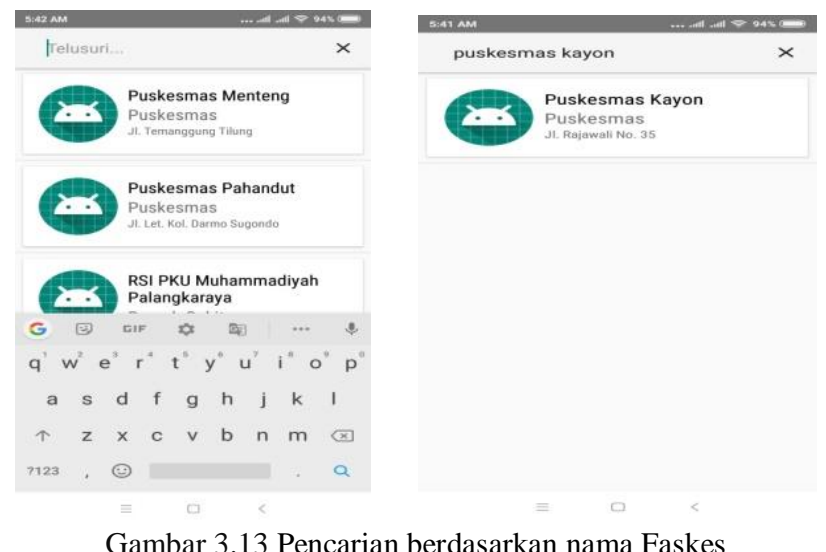

Gambar 3.13 Pencarian berdasarkan nama Faskes

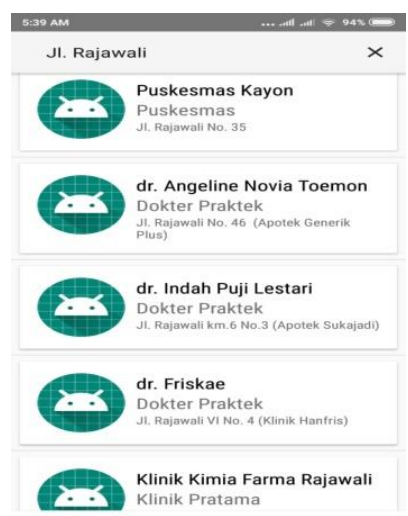

Gambar 3.14 Pencarian berdasarkan alamat Faskes

\subsubsection{Tampilan menu tentang}

Pada halaman utama juga terdapat fitur tentang, dimana fitur ini berisi uraian singkat tentang informasi aplikasi sistem informasi geografis pencarian faskes BPJS.

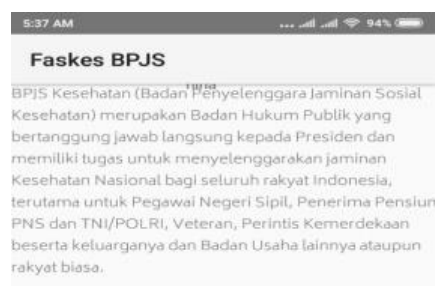

Gambar 3.15 Menu Tentang

\section{Kesimpulan}

Kesimpulan yang dapat diambil dari pembuatan serta penyelesaian Tugas Akhir dengan judul Rancang Bangun Sistem Informasi Geografis Fasilitas Kesehatan BPJS Berbasis Android di Kota 
Palangka Raya adalah aplikasi ini dirancang menggunakan software Android Studio dengan bahasa pemrograman Java dan database MySQL yang dikoneksikan dengan XAMPP, hingga UML (Unified Modeling Language) untuk untuk penggambaran sistem yang akan dibuat. Aplikasi ini hanya menyediakan informasi dari lima kategori fasilitas kesehatan berupa rumah sakit, puskesmas, klinik pratama, dokter praktik dan apotek yang bermitra dengan BPJS. Hasil dari pengujian blackbox tasting menyatakan bahwa fungsionalitas dari sistem informasi geografis fasilitas kesehatan BPJS di Kota Palangkaraya berjalan dengan baik dan sesuai fungsinya. Kedepannya apabila ada yang ingin menyempurnakan aplikasi ini diharapkan dapat menambahkan jenis-jenis layanan kesehatan dan menambahkan lokasi faskes yang dapat dilacak berdasarkan jarak radius terdekat dari posisi user berada, serta dari sisi multimedia untuk tampilan lebih menarik.

\section{Daftar Pustaka}

[1] Abidin, H.Z. 2007. Penentuan Posisi dengan GPS dan Aplikasinya. Pradnya Paramita: Jakarta

[2] Winarno, Edy dan Ali Zaki. 2013. Belajar Pemrograman Populer 3 in 1 : Java, VB dan PHP. Semarang. Alex Media Komputindo

[3] Fikri. R. 2005. Pemrograman Java. Yogyakarta. Penerbit Andi

[4] Nugroho.A. 2008. Pemrograman Java Menggunakan IDE Eclipse.Yogyakarta : Penerbit Andi.

[5] Nugruho. Heru. Fajar. 2013. “Aplikasi Mobile Pencarian Lokasi Distro di Yogyakarta Berbasis Android”. Yogyakarta. Sekolah Tinggi Manajemen Informatika dan Komputer AMIKOM Yogyakarta.

[6] Rosa, A.S dan M.Shalahuddin. 2013. Rekayasa Perangkat Lunak. Bandung: Informatika.

[7] Riyanto. 2010. Sistem Informasi Geografis Berbasis Mobile. Yogyakarta: Gava Media.

[8] Safaat, H. Nazaruddin. 2012. Pemrograman Aplikasi Mobile Berbasis Android. Bandung. Informatika

[9] Hendayani, 2012. "Sistem Informasi Geografis Pencarian Automatic Teller Machine (ATM) Wilayah Kota Palangkaraya Menggunakan Algoritma Haversine Berbasis Android”. Teknik Informatika. Universitas Palangkaraya.

[10] Developers Android Studio, "Mengenal Android Studio, http://developer.android.studio.com/studio/intro. Diakses pada tanggal 4 Desember 2018.

[11] Ma'rifah, Anis. 2012. "Aplikasi Pemetaan Fasilitas Kesehatan BPJS di Wilayah Sidoarjo Berbasis Google Maps". http://www.academia.edu/28216643/SKRIPSI APLIKASI_PEMETAAN_FASILITAS_KESEHATAN_BPJS_DI_WILAYAH_SIDOARJO_BERBASIS_ GOOGLE_MAPS.

[12] https://faskes.bpjs-kesehatan.go.id, diakses pada tanggal 30 Juni 2019.

teddy@ic.utm.my 